\title{
Academic training of nursing professionals and its relevance to the workplace ${ }^{1}$
}

\author{
Maria del Carmen Barbera Ortega ${ }^{2}$ \\ Diana Cecagno ${ }^{3}$ \\ Ana Myriam Seva Llor ${ }^{4}$ \\ Hedi Crecencia Heckler de Siqueira ${ }^{5}$ \\ Maria José López Montesinos ${ }^{6}$ \\ Loreto Maciá Soler ${ }^{7}$
}

\begin{abstract}
Objective: to identify the training nursing professionals receive and its relevance to the workplace, as well as professional demand for continuous education. Methodology: this was a descriptive observational study using a questionnaire entitled "Training and Adaptation of the Nursing Professional to the Workplace" available at: http://enfermeriadocente.es for nursing professionals. Results: $53.8 \%$ of nurses do not consider the training received to be relevant to the needs of the workplace and $94.2 \%$ reported that linking academic education to the workplace impacts on the quality of care provided. Conclusions: Nursing professionals think that continuous education needs to be adjusted to their jobs and careers. Education should be viewed as a continuum, which begins with training.
\end{abstract}

Descriptors: Nurses; Education; Quality of Health Care; Employment.

\footnotetext{
${ }^{1}$ Paper extracted from doctoral dissertation "Adequacy of academic postgraduate training of the nurse job in Murcia", presented to Facultad de Enfermería, Universidad de Murcia, Murcia, Spain.

2 PhD, Professor, Facultad de Enfermería, Universidad Católica de Murcia, Murcia, Spain.

${ }^{3}$ MSc, Assistant Professor, Faculdade de Enfermagem, Universidade Federal de Pelotas, Pelotas, RS, Brazil. Scholarship holder from Coordenação de Aperfeiçoamento de Pessoal de Nível Superior (CAPES), Brazil.

4 PhD, Associate Professor, Facultad de Enfermería, Universidad de Murcia, Murcia, Spain.

${ }^{5}$ PhD, Full Professor, Escola de Enfermagem, Universidade Federal do Rio Grande, Rio Grande, RS, Brazil.

${ }^{6}$ PhD, Full Professor, Facultad de Enfermería, Universidad de Murcia, Murcia, Spain.

7 PhD, Full Professor, Facultad de Enfermería, Universidad de Alicante, Alicante, Spain.
}

Corresponding Author:

Maria del Carmen Barbera Ortega

Universidad de Murcia. Facultad de Enfermería

C/ Don Juan de Borbón, 52

Sangonera la Verde

30833, Murcia, España

E-mail: mbo_may@yahoo.es
Copyright (c) 2015 Revista Latino-Americana de Enfermagem This is an Open Access article distributed under the terms of the Creative Commons Attribution Non-Commercial License (CC BY-NC).

This license lets others distribute, remix, tweak, and build upon your work non-commercially, and although their new works must also acknowledge you and be non-commercial, they don't have to license their derivative works on the same terms. 


\section{Introduction}

The technical and scientific advances with which we are faced daily in the field of health care, coupled with greater information on the part of the user, calls for increased quality of care received. This should be administered by technical and ethical professional actions and also depends on anything that affects the quality of services provided both in terms of material and human resources ${ }^{(1)}$.

The relationship between higher education, society and the labor market has contributed to the planning and management of Curricula in order to identify the forms, methods and content that higher education should take on, in order to contribute in a more appropriate way to social, economic and cultural development, catering to the needs of clients/patients, from a bio-psycho-social viewpoint (2).

Some of the most significant relationships between higher education and society dimensions are those associated with the satisfaction of graduates in their job. In any public or private organization it is important that the employer has a high degree of satisfaction, since this affects the efficiency of professional tasks to be performed

Some of the most significant dimensions of the relationships between higher education and society are those associated with graduate job satisfaction. In any public or private organization it is important that the employee has a high level of satisfaction, as this affects the efficiency with which they perform their professional tasks ${ }^{(3)}$.

Within health organization, training professionals and their future professional activity must be supervised in order to meet criteria and ensure quality in the provision of care(4).

In the Spanish Health Care System management depends on the kind of organizational system used, the technology applied, policies, work philosophy, existing resources, and the purpose and functions of the individual (5).

High demand for health care services, and the subsequent overload of work generated, makes it increasingly necessary for service organizations to generate a theoretical model that fits with the position, capabilities and technical and personal skills of the nurse.

Our current system of training in the European Higher Education Area (EHEA) is channeled through three subsystems: Undergraduate Teaching, Masters Teaching and Doctorate Teaching. The system is responsible for providing training which provides skills needed, and to facilitate the acquisition of skills needed for the labor market, as the nursing graduate is incorporated into it (6).

Currently, university nursing education, following the guidelines in the "Nursing Degree Handbook" by the National Quality Agency (ANECA), aims to train "Nurses responsible for general care"(7). In this document the profiles and objectives of the Nursing Graduate are also laid out.

Speaking of professionals' academic training, a distinction must be made between undergraduate academic training, which leads to the official qualification of Graduate in Nursing in order to exercise that profession in the healthcare sector, and academic background which includes postgraduate university education at different academic levels (Master, Doctorate) and training and refresher courses and scientific events.

The health sector is an environment that undergoes rapid changes and advances in knowledge through research and the introduction of new technologies, etc. For this reason, it is essential that health care professions, including nurses, update and complement their academic training so as to offer quality care and practice based on scientific evidence.

In general terms we can say that the Degree in Nursing is aimed at training professionals in general nursing with scientific and human preparation and development sufficient to assess, identify, implement and evaluate health needs and care for the healthy and the sick by training families and the community ${ }^{\left({ }^{8}\right)}$. Given this perspective, the study of postgraduate training for nursing graduates is established from multiple emergent, ideographic and reconstructive methodologies, given the current conditions of the training process in nursing and adapting it to the needs of professional practice (9). The present study aims to identify nurses' training and its adequacy for the job they perform, as well as professional demand for continuing education.

\section{Methods}

This was a cross-sectional observational descriptive study which took place in 2011-2012. In this period the "Training and Adaptation of the Nursing Professional to the Workplace (TANPW)" questionnaire was developed and can be found at http://enfermeriadocente.es. The study was conducted with nurses in Murcia. The study population was all of the qualified nurses in the Region 
of Murcia $(\mathrm{N}=2100)$. Criteria for inclusion were: Nursing professionals registered with the Murcia College of Nursing (COEMUR) whose e-mails were included in their database.

The sample was formed of 314 registered nurses in the Region of Murcia. This was calculated using a previous study ${ }^{(10)}$ as a reference, and met the inclusion and exclusion criteria in order to estimate the proportion with an estimated maximum error of $5 \%$ and a confidence level of $95 \%$. The technique used was convenience sampling, selecting individuals who completed the questionnaire voluntarily. The questionnaire was sent by e-mail to the entire study population in order to ensure a response rate at least equal to the calculated sample size. Responses to the questionnaire were received in January and February 2012.

The main source of information for investigating the field are nursing professionals, as well as sources of information derived from the Laws, Orders, Regulations and Royal Decrees relevant to this study and in effect in Spanish territory.

The "Training and Adaptation of the Nursing Professional to the Workplace (TANPW)" questionnaire, available at http: //enfermeriadocente.es, was developed and designed based on a bibliographic review and on the opinion of experts in the area using the Nominal Group technique. The content of the instrument was validated using a pre- test.

The final questionnaire was made up of the following dimensions classified into 5 blocks: BLOCK 1 Socio-demographic and Socio-laboral Variables; BLOCK 2 Academic training and the year in which studies were completed; BLOCK 3 Continuous Education; BLOCK 4 Nursing training would like to receive; BLOCK 5 Personal perception of the training received.

The results were analyzed using descriptive statistics showing the frequencies and percentages observed for the different variables studied. Inferential statistical analysis was then performed, in which bivariate relationships of the discrete numeric variables (number of years in the position, number of courses) were analyzed using Pearson's coefficient of correlation (r). Statistical analysis of the differences in mean values for these discrete numerical variables was conducted using the t-student test for independent samples or the on-way ANOVA, as appropriate. To evaluate the influence of these variables studied on the principal variables in question, we used multi-variables logistic regression, using the backward stepwise Wald method to ensure that the inclusion of all variables in the models was not due to artifacts or interactions.
The study was approved by the Ethic committee of the Murcia College of Nursing and participants signed an informed consent form before accessing the questionnaire.

\section{Results}

Profile of the population: the mean age of the population was 40 years old. The population was very homogeneous with regards age. The ages of $95 \%$ of the subjects surveyed were within 10 years of the mean age of the population.

As for gender, $31 \%$ were male, while $69 \%$ were female, as shown below.

Regarding the highest level of academic education, most of the participants held a university diploma in Nursing, at the time of the study, only 10 subjects held an undergraduate degree and 3 had doctorates, as shown in Table 1.

Table 1 - Level of academic education reached by the nursing professionals according to age, gender and workplace, Murcia, Spain 2011-2012

\begin{tabular}{lcc}
\hline Academic Training & Frequency & Percentage valid \\
\hline Diploma in nursing & 201 & 64.0 \\
Degree in nursing & 10 & 3.2 \\
Specialty & 33 & 10.5 \\
Master & 48 & 15.3 \\
Doctorate course & 6 & 1.9 \\
research proficiency & 13 & 4.1 \\
Doctorate & 3 & 1.0 \\
Total & 314 & 100.0 \\
\hline
\end{tabular}

Source: Barbera Ortega MC. "Adecuación de la Formación del Profesional de Enfermería en la Región de Murcia". Doctoral Thesis. Universidad de Murcia. 2014.

In order to discover the whether the training received was appropriate to the professional functions, it was analyzed whether the nurses themselves considered their training appropriate, or not, to the needs of their workplace. Of the 314 questionnaire replies, approximately $53.8 \%$ of the nurses considered that the training received was not appropriate to the needs of their workplace, while $46.2 \%$ considered it appropriate to their professional needs.

Regarding the training the nursing personal would like to receive, we analyzed what was first place in demand for each of the nurses consulted and ranked them in order of frequency, as can be seen in Table 2 .

As for the appropriateness of training received to workplace needs, although the majority of those surveyed stated that they did training courses at their 
workplace, they also revealed that they felt the need for more training. This apparently contradictory data may be explained by the fact that around $53.8 \%$ of the nurses considered that the training they received was not adapted to the needs of their workplace.

When we asked whether training linked to the workplace impacted on the quality of care provided, the majority $(94.2 \%)$ of those surveyed considered that it was not only important, but very important and only 2 of the 314 nurses surveyed stated that it was of little importance.

Table 2 - First place in training desired according to professional and workplace needs. Murcia, Spain 20112012

\begin{tabular}{lcc}
\hline Workplace & Frequency $(\mathbf{n})$ & Percentage (\%) \\
\hline Intensive & 71 & 22.3 \\
Geriatric & 15 & 4.7 \\
Mental health & 11 & 3.5 \\
Quality management & 25 & 7.8 \\
Women's health & 17 & 5.3 \\
Pediatrics & 30 & 9.4 \\
Surgery & 44 & 13.8 \\
Management / administration & 9 & 2.8 \\
Nursing Methodology & 11 & 3.4 \\
Research & 21 & 6.6 \\
New technology & 17 & 5.3 \\
Health education & 22 & 6.9 \\
Other & 21 & 6.3 \\
Total & 314 & 6.6 \\
\hline
\end{tabular}

Source: Barbera Ortega MC. "Adecuación de la Formación del Profesional de Enfermería en la Región de Murcia". Doctoral thesis. Universidad de Murcia. 2014.

\section{Discussion}

The data was collected based on statements of the professionals, in other words, what they "say they do" and "say they received", and on their opinions about the appropriateness of the training they received in relation to their performance at work. .

When we analyzed the highest level of academic education received, the sample of nurses from Murcia studied was formed mainly of those with university Diplomas in Nursing, 62\%, followed by those with Master's $15 \%$, and $1 \%$ with a Doctorate, reflecting the interest shown in ongoing education and academic growth.

Education in Nursing has undergone a series of changes which have led to evolutions in the training of these professionals. One of the most significant of these was in 1953, after Spain joined the World Health Organization (WHO) and accepted that agency's guidelines on health care subjects, unifying the previous three qualifications of Practitioner, Matron and Nurse into a single one: Assistant Health Technician (11). With the Diploma in nursing, another unprecedented function of nursing appeared, that of teaching. From 1977 onwards, a distinction has been made between the two field of teaching for nursing professionals, training nursing personnel and health information and education for individuals and the community. In Spain, gaining a Doctorate in nursing has only recently become possible. Our data show that $1 \%$ of the nurses surveyed had achieved this level. . To date, those with a Diploma in Nursing accessed the doctorate degree through other higher university degrees. The changes in the nursing profession in recent years and limited research activity should be taken into account in order to enhance and promote research capacity and support the nurse and thus provide a basis for care practice, innovating to ensure they are of the highest possible quality ${ }^{(12)}$.

As for the demand for training for nursing professionals, $90 \%$ of those surveyed indicated that they needed more training in order to carry out their professional activities. In fact, there are studies which show that more training improves the quality of patient care and reduces adverse effects ${ }^{(13-14)}$.

The results obtained highlight that those nurses who occupy positions in hospitals did not encounter obstacles to continuous education, consider quality of care to be very important, have easy access to training, and those who do courses at their workplace are the ones with the highest chances of deeming their training to be appropriate. Although these aspects are important in discovering the nurses' own opinions about their training, they cannot determine whether that training is really appropriate or not. This can only be determined using specific tests or performance analysis, or studying adverse effects as a consequence of poor nursing practice, which was not one of the aims of this project, and thus, although important, were not among the aspects evaluated.

Another factor associated with the appropriateness of continuous education is the role of management. Those nurses holding this type of position were 2.4 times more likely to consider their training appropriate to their workplace ${ }^{(15)}$. We consider that knowledge of management is linked to the professional's security in stating that the training is appropriate to the position they hold. Moreover, outside of the health care area, the literature consulted describes the need for high levels of training in order to move up from technical positions to 
a management role(16), and it is not illogical to think that the same circumstances may apply to Nursing.

Being aware of training demands for nurses and training needs could be seen as the initial step of a cyclical process that contributes to global education and education strategies for the personnel of an organization or group of professionals. Another aspect which it is important to correctly evaluate are their training needs; who is interested in nurses' training? In principle, we could say that only nurses are interested, but in truth, there are others with an interest, such as service users or clients/patients, who are those that will eventually benefit from the training. Moreover, we must also take into account those who provide the training (public, private etc.) and finally the managers who are responsible for ensuring quality service ${ }^{(17)}$.

Analyzing training needs may be a relatively recent field in the area of Nursing, but it has been used for many years in work areas such as human resources, business and industry and in education in general ${ }^{(18)}$. Study of the training needs of nursing staff can be conducted on two levels, on the micro level, which concerns studies conducted in a particular unit or clinic/hospital or studies on a macro level, referring to an entire service or Region. This is the type of study most often found in the literature reviewed ${ }^{(19)}$.

When evaluating the needs for nursing training we are obliged to refer to the work of other authors (20), as the first exponents of the scientific methodology for developing the questionnaire used to evaluate nurses' training needs, on which we based the design of one of the dimensions of this study, "Nursing training they would like to receive". In our study, the most type of training which was most often first on the list was for intensive care, with $22.3 \%$, followed by training for surgical medicine.

Faced with this training demand, we must once again ask ourselves in which environment it should be delivered in the current situation of professional nursing. New nursing professional skills, as well as medical and scientific developments in the techniques to be delivered, free movement of nursing professionals, today's cultural and social diversity which may determine more the need and demand for more concrete but, at the same time, more extensive training. Reviewing the literature on this topic, various types of training appear that were not included in this study and, curiously, were not mentioned by any of the nurses consulted, such as learning a second language, specifically English (21) statistics $^{(22)}$ or training in the ethical aspects of nursing (23).
Previous studies on the topic (20-22) focused on analyzing training needs for research, and found data similar to those of this study, in the sense that the most in demand training referred to technical nursing abilities, followed by caring for suicidal patients, and then by training in areas of study encouraging early clinical detection in managing care. This situation is probably related to the nursing professionals' previous training as, in theory, graduates in Nursing possess a range of basic skills with which to effectively deal with methodological and research needs, generating groups of nurses at work who are differentiated; more experienced nurses with more training in clinical aspects of patient care, and recently graduated nurses with more methodological/ theoretical training.

Another in-demand training need was that of nursing methodology. In fact, this was one of the most attractive aspects for recent graduates. As some authors have noted, it is necessary to learn about knowledge and nursing's contribution to health care in order to strengthen the role of the nursing professional in contributing to the health of the population, improving postgraduate training ${ }^{(24)}$. On completing their education and joining the workforce, students find it difficult to put into practice the nursing models and work methodologies they have learnt, adapting themselves to a system of functioning that merely provides care. One possible solution to this conflict may be continuous training, as some authors view this as the most appropriate way of maintaining professional competence and guaranteeing adaptation to new scientific-technological advances, enabling deficiencies in training to be corrected and encouraging the correct use of health care services, guaranteeing quality(24-25).

\section{Conclusions}

The reality of academic training for nursing professionals has changed radically in recent decades, in terms of maintaining the rhythm of current clinical practice, "new" nursing professionals should have more knowledge of certain areas of work, meeting the population's health and social need.

Most of the nursing professionals consulted consider that their postgraduate academic training is not appropriate to their workplace. This situation occurs in spite of the majority of them stating that they had done continuous education courses or had attended congresses, training days or seminars, showing that the training received by the professionals surveyed was 
not appropriate to the needs of their work, nor to their academic education.

Nurses' previous training has significant impact on their perception of their training needs. Specifically, those with university diplomas in nursing are at more risk of demanding information than those with degrees/ specializations, for which reason extra attention must be paid to this group with regards ongoing education.

Nursing professionals deem it necessary to adapt continuous education to the workplace and to their careers.

In our opinion, professional training should be viewed as a continuum, which begins with basic training and should continue throughout professional life. It is, in any case, very difficult to show the impact of appropriate training on clinical practice and therefore on services provided, and this remains unevaluated in the literature. In this study of training needs, we have remained at the first step, which is to say, studying nurses' training demands. The data obtained may help in designing education strategies which should be established and their effectiveness evaluated.

Limitations of this study include selecting the sample, as the questionnaires were completed voluntarily by the professionals, and not selected through probabilistic sampling.

\section{References}

1. Ureña Vilardell V. La calidad de la atención sanitaria: definición, historia y conceptos básicos. Calidad y Riesgo. 2001;1(1):46-66.

2. Oliva C, Hidalgo CG. Satisfacción Usuaria: Un Indicador de Calidad del Modelo de Salud Familiar, evaluada en un Programa de Atención de Familias en Riesgo Biopsicosocial, en la Atención Primaria. Psykhe. 2004;13(2):173-86.

3. Córdova Delgado M, Alvarado Alfaro $S$, Manrique Manrique $\mathrm{H}$, Lizarbe Choquea $\mathrm{CR}$, Aguirre Alvarad SE, Huaman Ichpas J. Calidad de vida laboral de los egresados y predicamento del empleador. Facultad de Enfermería de la Universidad Nacional "San Luis Gonzaga" de ICA 2013. Rev Enferm Vanguard. 2014;2(2):154-60.

4. Carbajo P, Castrodeza J, Gual A, López-Blanco JA, Martín-Zurro A, Sánchez-Biezma E. Desarrollo, seguimiento y evaluación de la formación especializada en el modelo troncal: conclusiones del seminario realizado el 24 de septiembre de 2014 en la XXV Escuela de Salud Pública, Llatzaret, Menorca. FEM. [Internet]. 2014 [acesso 18 out 2014]; 17(4):193-
7. Disponível em: http://dx.doi.org/10.4321/S201498322014000400004.

5. Raventos J. ¿Es hoy determinante invertir en el desarrollo de las organizaciones? Capital Humano. 2004;181:16.

6. González Veiga MC, Cueto Iglesias B, Mato Díaz J. ¿Qué beneficios tiene para la empresa su colaboración con el sector educativo? Un análisis de la formación de centros de trabajo desde la perspectiva empresarial. Rev Ministerio de Trabajo e Inmigración. 2010;76:39-58.

7. ANECA Agencia Nacional de Evaluación de la Calidad y Acreditación (ES). Libro Blanco del Título de Enfermería. Madrid; 2004.

8. García C, Gómez García CI, Antón Hurtado F. La comunicación interprofesional desde la cultura organizacional de la enfermería asistencial. Cultura de Ios cuidados: Rev Enferm Humanidades. 2011;31:85-92. 9. Medina FJ, Gallardo R, Gómez J. La vía Máster oficial para Enfermería de Urgencias, Emergencias y cuidados críticos. Emergencias. 2009;21:283-6.

10. López Montesinos MJ. Consecuencias Psicosociales del trabajo en personal de Enfermería como indicadores subjetivos de rendimiento desde el enfoque de la gestión de los Recursos Humanos. [Tesis Doctoral]. Murcia: Universidad de Murcia; 2009.

11. Maciá Soler L, Zabalegui Yárnoz A. Desarrollo del máster y doctorado oficial de enfermería en España. Castellón: Universidad Jaume I. Servicio de Comunicación y Publicaciones; 2010.

12. Francisco del Rey C. De la práctica de la enfermería a la teoría enfermera. Concepciones presentes en el ejercicio profesional. [tesis Doctoral]. Alcalá de Henares: Universidad Alcalá de Henares (Madrid); 2008.

13. Bowie $P$, Skinner J, de Wet $C$. Training health care professionals in root cause analysis: a cross-sectional study of post-training experiences, benefits and attitudes. BMC Health Serv Res. 2013;7(13):50.

14. Poh CL, Parasuram R, Kannusamy P. Nursing intershift handover process in mental health settings: a best practice implementation project. Int J Evid Based Healthc. 2013;11(1):26-32.

15. Barbera Ortega MC. "Adecuación de la Formación del Profesional de Enfermería en la Región de Murcia". [Tesis Doctoral]. Murcia: Universidad de Murcia; 2014.

16. Fernández Losa N. El desarrollo profesional de los trabajadores como ventaja competitiva de las empresas. Cuad Gestión. 2002;2(1):65-90.

17. Gould D, Kelly D, White I, Chidgey J. Training need analysis. A literature review and reappraisal. Int J Nurs Stud. 2004;41:471-86. 
18. González Juanatey JR. Las sociedades científicas y la formación médica. El papel de la Sociedad Española de Cardiología. Cardiocore. [Internet]. 2014 [acesso 18 out 2014];49(Enero-Marzo). Disponível em: http://www. redalyc.org/articulo.oa?id=277031274005

19. Tizón Bouza E, Marcos Espino MP ¿Es posible el uso de la evidencia científica en la formación de especialistas de enfermería comunitaria y familiar?. ENE Rev Enferm. 2013;7(3):1-5.

20. Santos JC, Simões RMP, Erse MPQA, Façanha JDN, Marques LAFA. pact of "+Contigo" training on the knowledge and attitudes of health care professionals about suicide. Rev. Latino-Am. Enfermagem. 2014;22(4):679-84.

21. Camacho-Bejarano R., Barquero-González A, Mariscal-Crespo MI, Merino-Navarro D. English in the nusing degree: a pending subject. Rev. Latino-Am. Enfermagem. 2013;21(2):641-8.

22. Hagen B, Awosoga O, Kellett P, Dei SO. Evaluation of undergraduate nursing student's attitudes towards statistic courses, before and after a course in applied statistics. Nurse Educ Today. 2013;33:949-55.

23. Kalaitzidis E, Schmitz, K. A study of an ethics education topic for undergraduate nursing students. Nurse Educ Today. 2012;32(1):111-5.

24. ShamianI, J. El papel de la enfermería en la atención sanitaria. Rev Bras Enferm. 2014;67(6):871-2.

25. Jiménez Navarro, Manuel F, Romero Rodríguez, Nieves, Muñoz García, Antonio J, Arana Rueda E, Cabrera Bueno F. Formación Médica Continuada. Una necesidad desde diferentes prismas Cardiocore. [Internet]. 2014 [acesso 18 out 2014];49(Enero-Marzo): Disponível em: http://redalyc.org/articulo.oa?id=277031274001 